\title{
Strategi Pembelajaran Menulis Puisi Reflektif untuk Siswa SMA Kelas $\mathrm{X}$
}

\author{
Etsa Purbarani ${ }^{1}$, Abdus Syukur Ghazali ${ }^{1}$, Nita Widiati ${ }^{1}$ \\ ${ }^{1}$ Pendidikan Bahasa Indonesia-Universitas Negeri Malang
}

\begin{tabular}{l}
\hline \hline INFO ARTIKEL \\
\hline Riwayat Artikel: \\
Diterima: 22-11-2018 \\
Disetujui: 27-01-2019 \\
\hline
\end{tabular}

\section{Kata kunci:}

learning strategies;

writing poetry;

reflective poetry;

strategi pembelajaran;

menulis puisi;

puisi reflektif

\begin{abstract}
Writing poetry learning in school tends to be mechanistic and less direct students in creative process that cause difficulty and decrease students' motivation on writing poetry. Therefore, the researcher develops poetry writing learning strategy, that is learning strategy of writing reflective poetry which is packaged in a guidebook designed for teachers. Based on those explanations, this development aims to (1) developing products in the form of learning strategies to write reflective poems, (2) develop a guide of the implementation of a reflective poetry writing strategy that designed for teachers, and (3) reported the product feasibility test of reflective poetry writing strategy.
\end{abstract}

ABSTRAK

\begin{abstract}
Abstrak: Selama ini, pembelajaran menulis puisi di sekolah cenderung bersifat mekanistik dan kurang mengarahkan siswa untuk berproses kreatif. Hal tersebut menjadikan siswa mengalami kesulitan dan penurunan motivasi dalam menulis puisi. Oleh karena itu, dikembangkan strategi pembelajaran menulis puisi, yaitu strategi pembelajaran menulis puisi reflektif yang dikemas dalam bentuk buku panduan dan ditujukan untuk guru. Berdasarkan paparan tersebut, penelitian pengembangan ini bertujuan untuk (1) mengembangkan produk berupa strategi pembelajaran menulis puisi reflektif, (2) mengembangkan panduan penerapan strategi pembelajaran menulis puisi reflektif yang penggunaannya ditujukan untuk guru, dan (3) melaporkan uji kelayakan produk strategi pembelajaran menulis puisi reflektif.
\end{abstract}

\author{
Alamat Korespondensi: \\ Etsa Purbarani \\ Pendidikan Bahasa Indonesia \\ Universitas Negeri Malang \\ Jalan Semarang 5 Malang \\ E-mail: etsapurbarani@um.ac.id
}

Menulis puisi adalah salah satu kompetensi yang diajarkan dalam pembelajaran Bahasa Indonesia di sekolah. Pada pemahaman yang lebih luas, menulis puisi dimaknai sebagai upaya mengomunikasikan pemikiran, perasaan, pengetahuan, gagasan, dan pengalaman melalui pemadatan unsur-unsur bahasa secara kreatif, estetik, dan orisinal (Bolton, 2014; DiYanni, 2001; Kennedy dan Guioa, 1994; Waluyo, 1987). Dalam konteks pembelajaran di sekolah, menulis puisi menekankan pada keterampilan siswa pada eksplorasi bentuk-bentuk bahasa yang dilakukan dalam koridor estetis dengan tujuan untuk menuangkan ide, gagasan, dan perasaan melalui cara yang implisit. Selain itu, pembelajaran menulis puisi yang terlaksana dengan baik dapat membentuk pribadi siswa menjadi responsif, kritis, dan kreatif dalam menanggapi informasi serta berpikir dan bertindak secara orisinal (Naylor dan Wood, 2012).

Akan tetapi, fakta di lapangan menunjukkan bahwa puisi cenderung dimaknai sebagai karya sastra yang mengekspresikan luapan emosi sementara. Oleh karena itu, pembelajaran menulis puisi di sekolah cenderung bersifat mekanistik dan kurang mengarahkan siswa untuk berproses kreatif (Endraswara, 2003). Padahal, untuk dapat menghasilkan karya puisi yang bermutu dan prosesnya dapat pula membentuk kepribadian siswa, siswa harus terlibat secara langsung di dalam proses kreatif agar dapat membentuk daya imajinasi sebagai realisasi gagasan, ide, dan perasaan estetik ke dalam gambaran-gambaran yang lebih konkret (Maulana, 2015; Rahmanto, 2000).

Dalam pengajaran kompetensi menulis puisi, guru cenderung mengajarkan kompetensi tersebut dengan mengangkat pengalaman yang terpisah atau tidak dihayati siswa secara nyata. Misal, menugaskan siswa untuk menulis puisi tentang keindahan alam dengan hanya bermodalkan gambar, sementara siswa belum pernah merasakan suasana alam yang dijadikan referensi oleh guru. Contoh lainnya adalah penugasan siswa untuk menulis puisi yang mengangkat isu sosial tentang anak jalanan atau kemiskinan, tetapi siswa belum benar-benar memahami dan melihat langsung secara nyata permasalahan sosial tersebut. Faktor penugasan yang seringkali sepele dan dianggap cukup tersebut juga menjadikan siswa kurang terlibat di dalam proses kreatif menulis puisi karena sumber penulisannya tidak berasal dari pengalaman hidup yang memang dialami, dirasakan, dan dihayati oleh siswa. Kurangnya pelibatan siswa dalam berproses kreatif berakibat pada menurunnya motivasi dan munculnya berbagai kesulitan untuk siswa dalam menulis puisi. 
Berdasarkan data yang dihimpun di lapangan, kesulitan-kesulitan yang dialami siswa dalam menulis puisi meliputi (1) sulit menemukan ide penulisan puisi, (2) memiliki sedikit variasi kosakata, (3) sulit membangun suasana puisi, dan (4) sulit dalam merangkai kata-kata menjadi larik puisi yang bermakna. Berdasarkan fenomena tersebut, peneliti mengembangkan strategi pembelajaran menulis puisi yang berpijak pada tiga kriteria, yaitu (1) mudah diajarkan oleh guru, (2) mudah diterapkan oleh siswa, dan (3) mampu membimbing siswa untuk berproses kreatif menulis puisi (Roseboro, 2010). Oleh karena itu, peneliti mengembangkan strategi pembelajaran menulis puisi reflektif yang dikemas dalam bentuk buku panduan dan ditujukan untuk guru. Produk tersebut diharapkan dapat (1) membantu guru untuk membimbing siswa dalam berproses kreatif menulis puisi, (2) melibatkan siswa secara nyata untuk berproses kreatif menulis puisi secara langsung, dan (3) melatih siswa untuk merefleksikan berbagai fenomena yang terjadi dan tersimpan sebagai pengalaman hidup melalui pemaknaan yang lebih dalam.

Strategi pembelajaran menulis puisi reflektif dikembangkan dengan memadukan dua proses berpikir, yaitu proses berpikir reflektif dan proses kreatif menulis puisi. Proses berpikir reflektif, meliputi empat tahap, yaitu (1) kehadiran serta pengenalan masalah dan situasi, (2) klarifikasi masalah, (3) pembangunan, pengujian, dan modifikasi hipotesis, serta (4) mengambil tindakan yang sesuai dengan situasi yang ada dan berjalan secara berurutan sebagai sebuah siklus yang berulang (Hullfish dan Smith, 1964; Bolton, 2014). Pelaksanaan proses berpikir reflektif tersebut melibatkan komponen-komponen mental manusia yang meliputi memori, imajinasi, sentiensi, dan emosi (Hullfish dan Smith, 1964; Rodgers, 2002). Proses berpikir reflektif tersebut kemudian diaplikasikan ke dalam proses kreatif menulis puisi yang terdiri atas (1) tahap penggalian dan pemunculan ide, (2) tahap perenungan ide, (3) tahap penuangan ide, (4) tahap koreksi dan revisi, serta (5) tahap introspeksi (Widijanto, 2014; Morley, 2007; Endraswara, 2003).

Dengan memadukan kedua proses berpikir tersebut siswa diharapkan mampu memproduksi karya puisi berupa puisi reflektif yang merefleksikan pemikiran dan sudut pandang mereka terhadap suatu masalah atau peristiwa yang diwujudkan secara unik, estetik, dan orisinal melalui eksplorasi keterampilan berbahasa. Untuk mencapai hasil belajar berupa puisi reflektif, penggalian ide puisi difokuskan pada pengalaman pribadi siswa yang berkesan dan membawa perubahan dalam hidup mereka. Pengalaman berkesan yang membawa perubahan dipilih sebagai ide menulis puisi reflektif karena pengalaman yang demikian merupakan sumber penemuan ide yang mengandung unsur keharuan atau guncangan hati sehingga dapat dituliskan sebagai puisi (Maulana, 2015; Situmorang, 1984; Dini, 1983; Atmowiloto, 1983).

Selain tujuan pembelajaran tersebut, aktivitas menulis puisi reflektif dapat menjadi sarana untuk mencapai tujuan pendidikan yang luas. Dalam konteks tujuan pendidikan yang lebih besar, membelajarkan keterampilan menulis puisi reflektif dapat menumbuhkembangkan dan memperkokoh tiga komponen karakter-pengetahuan moral, perasaan moral, dan tindakan moral - serta memberikan kesempatan secara nyata kepada siswa untuk mengembangkan pemaknaan hidup dari sudut pandang moral etis, sosial humanis, bahkan mungkin mencapai perspektif religiusitas (Rodgers, 2002; Lickona, 1992).

Berdasarkan paparan mengenai tujuan pembelajaran dan tujuan pendidikan yang diharapkan dapat dicapai melalui strategi pembelajaran menulis puisi reflektif, penelitian pengembangan ini memiliki tiga tujuan. Ketiga tujuan tersebut adalah (1) mengembangkan produk berupa strategi pembelajaran menulis puisi reflektif, (2) mengembangkan panduan penerapan strategi pembelajaran menulis puisi reflektif yang penggunaannya ditujukan untuk guru, dan (3) melaporkan uji kelayakan produk strategi pembelajaran menulis puisi reflektif.

\section{METODE}

Penelitian pengembangan ini mengadaptasi model prosedural dari Borg dan Gall. Pada model pengembangan yang asli, terdapat sepuluh langkah pengembangan yang meliputi (1) penelitian dan pengumpulan informasi awal, (2) perencanaan, (3) pengembangan format produk awal, (4) uji coba awal, (5) revisi produk, (6) uji coba lapangan, (7) revisi produk, (8) uji lapangan, (9) revisi produk akhir, serta (10) desiminasi dan implementasi (Borg dan Gall, 2003). Kesepuluh langkah pengembangan tersebut diadaptasi menjadi tujuh tahap pengembangan strategi pembelajaran menulis puisi reflektif. Ketujuh tahap tersebut adalah (1) studi pendahuluan, (2) perencanaan, (3) pengembangan draft produk, (4) uji validasi, (5) revisi produk awal, (6) uji lapangan terbatas, dan (7) penyempurnaan produk akhir.

Penerapan strategi pembelajaran menulis puisi reflektif dilaksanakan pada tahap keenam, yaitu uji coba lapangan terbatas. Pada uji coba lapangan terbatas tersebut, siswa akan mengikuti pembelajaran menulis puisi reflektif yang terdiri atas empat tahap. Keempat tahap tersebut meliputi tahap (1) refleksi pengalaman, (2) penulisan puisi, (3) perbaikan unsur puitika, dan (4) penyuntingan dan penyempurnaan.

Pertama, Tahap Refleksi Pengalaman. Pada implementasi Tahap Refleksi Pengalaman, aktivitas belajar yang dilakukan siswa adalah (1) menyaksikan iklan dan video/film pendek inspiratif kemudian merefleksikan pesan atau nilai kehidupan dari tayangan, (2) mengingat kembali pengalaman berkesan dan membawa perubahan yang pernah siswa alami selama lima menit, (3) memilih satu pengalaman berkesan dan membawa perubahan yang spesifik dalam kehidupan siswa, (4) menggali ingatan tentang rincian unsur-unsur di dalam pengalaman tersebut, (5) menulis rincian dan kronologis peristiwa dari pengalaman tersebut ke dalam urutan singkat, (6) menuliskan pengalaman berkesan yang membawa perubahannya ke dalam bentuk narasi yang diikuti dengan refleksi melalui panduan pertanyaan.

Kedua, Tahap Penulisan Puisi. Pada implementasi Tahap Penulisan Puisi, aktivitas belajar yang dilakukan siswa adalah (1) memilah narasi yang telah ditulis berdasarkan bagian-bagian alur, (2) merefleksikan unsur-unsur yang ada di dalam setiap bagian alur peristiwa, baik berupa gambaran sosok tokoh yang terlibat di dalamnya, kesan yang ada di dalam peristiwa itu, serta 
nilai atau pelajaran hidup yang dapat dirumuskan dari peristiwa tersebut, (3) mengimajinasikan bagian-bagian alur peristiwa sebagai peristiwa simbolis, (4) mengumpulkan diksi puitis berdasarkan hasil pengimajinasian, (5) merangkai larik-larik puisi dengan menggunakan diksi yang telah dikumpulkan, dan (6) menulis larik-larik yang telah dibuat ke dalam susunan bait yang padu dan menghasilkan draft puisi utuh.

Ketiga, Tahap Perbaikan Unsur Puitika. Pada implementasi Tahap Unsur Puitika, aktivitas belajar yang dilakukan siswa adalah (1) melakukan perbaikan pada diksi puisi dengan mengubah, menghilangkan, atau menambahkan pilihan kata yang lebih puitik atau lebih sesuai dengan maksud yang ingin diungkapkan, (3) memperkaya aspek citraan di dalam draft puisi yang telah ditulis dengan cara menentukan latar atau objek yang ada di dalam puisi kemudian mengimajinasikan suasana latar atau objek melalui penggambaran pancaindera, (4) memperkaya penggunaan majas atau bahasa figuratif di dalam puisi dengan cara membandingkan objek di dalam puisi dengan objek lainnya secara langsung atau tidak langsung, mengandaikan objek tak hidup di dalam puisi supaya dapat beraktivitas seperti manusia, dan/atau mengungkapkan objek di dalam puisi dengan cara yang berlebihan atau sebagai sesuatu yang luar biasa, (5) menata harmonisasi bunyi di dalam puisi, (6) memeriksa kesatuan ide dan pembangunan suasana di dalam puisi, serta (7) memberikan judul yang sesuai.

Keempat, Tahap Penyuntingan dan Penyempurnaan. Pada implementasi Tahap Penyuntingan dan Penyempurnaan, aktivitas belajar yang dilakukan siswa adalah (1) membentuk pasangan kerja dengan teman sebangku, (2) bertukar karya puisi dan membaca karya milik teman pasangan kerja, (3) memberikan pendapat, kritik, dan saran terhadap setiap puisi karya teman pasangan kerja, dan (4) memperbaiki kembali puisi yang sudah ditulis berdasarkan saran, kritik, dan komentar oleh teman pasangan kerja.

Desain uji produk dalam penelitian pengembangan ini menggunakan desain deskriptif sehingga seluruh hasil penelitian akan dideskripsikan. Uji coba produk pengembangan strategi pembelajaran menulis puisi reflektif terdiri atas dua jenis uji yang dilakukan berturut-turut, yaitu (1) uji kelayakan oleh ahli dan praktisi serta (2) uji coba lapangan terbatas. Uji kelayakan oleh ahli dan praktisi melibatkan dua ahli, yaitu (1) ahli puisi dan (2) ahli pembelajaran puisi, sedangkan praktisi bahasa Indonesia yang menjadi validator adalah guru bahasa Indonesia kelas X-Bahasa dan Budaya di SMA Negeri 1 Batu. Pada uji coba lapangan terbatas, subjek uji adalah siswa dalam kelompok terbatas, yaitu siswa Kelas X-Bahasa dan Budaya SMA Negeri 1 Batu yang berjumlah 34 orang.

Instrumen penelitian yang digunakan dalam pengembangan strategi pembelajaran menulis puisi reflektif terdiri atas (1) pedoman wawancara digunakan pada studi pendahuluan dan uji kelayakan, (2) lembar observasi digunakan pada uji coba lapangan terbatas untuk memperoleh data hasil kegiatan pembelajaran menulis puisi melalui implementasi strategi pembelajaran menulis puisi reflektif, dan (3) angket digunakan pada uji kelayakan produk oleh ahli dan praktisi serta pada uji lapangan terbatas oleh siswa.

Data yang diperoleh dari penelitian pengembangan strategi pembelajaran menulis puisi reflektif meliputi dua jenis data. Kedua jenis data tersebut adalah (1) data verbal, berupa data verbal tertulis berupa catatan, komentar, kritik, saran pada lembar angket para subjek uji, teks puisi reflektif karya siswa yang dihimpun dari uji coba lapangan terbatas; dan data verbal lisan berupa hasil wawancara dan masukan-masukan secara lisan dari ahli maupun praktisi; serta (2) data numerik berupa skor yang diperoleh dari angket yang diisi oleh para subjek uji kelayakan dan subjek uji lapangan terbatas. Teknik analisis data yang digunakan adalah teknik analisis kualitatif dan teknik analisis kuantitatif. Teknik analisis kualitatif digunakan untuk menganalisis data verbal dari wawancara informal dan catatan tertulis berupa komentar, saran, dan masukan pada angket, baik angket uji validasi ahli dan praktisi maupun angket uji lapangan terbatas, sedangkan teknik analisis kuantitatif digunakan untuk menganalisis skor yang diperoleh dari angket uji validasi oleh ahli dan praktisi serta angket uji coba lapangan terbatas yang diisi oleh siswa. Selanjutnya, data numerik tersebut diolah melalui penghitungan dengan rumus berikut.

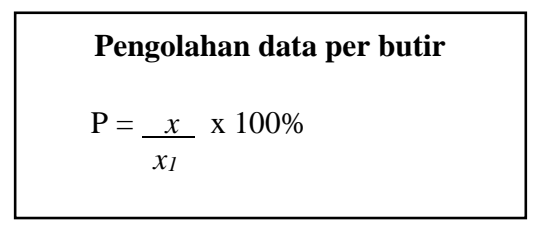

\begin{tabular}{|c|}
\hline $\begin{array}{c}\text { Pengolahan data angket secara } \\
\text { keseluruhan }\end{array}$ \\
$\mathrm{P}=\frac{\Sigma x}{\Sigma x_{1}} \times 100 \%$ \\
\hline
\end{tabular}

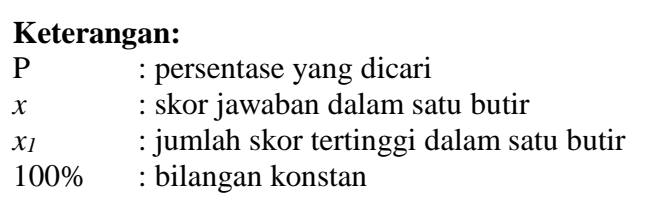

Penghitungan yang dilakukan pada seluruh data numerik di masing-masing angket subjek uji akan menghasilkan persentase yang nantinya dikelompokkan berdasarkan kriteria tertentu untuk mengetahui tingkat kelayakan penerapan produk. Kriteria kelayakan berdasarkan persentase hasil uji dikelompokkan, sebagaimana ditunjukkan pada Tabel 1. 
Tabel 1. Persentase Kriteria Kelayakan Produk

\begin{tabular}{cccc}
\hline & Hasil Uji & & Tindak Lanjut \\
$\begin{array}{c}\text { Kategori } \\
\text { Skor }\end{array}$ & Persentase & Kualifikasi & \\
\hline 4 & $85 \%-100 \%$ & Sangat layak & Implementasi \\
3 & $75 \%-84 \%$ & Layak & Implementasi dengan sedikit revisi \\
2 & $55 \%-74 \%$ & Cukup layak & Revisi sesuai catatan ahli dan praktisi \\
1 & $<55 \%$ & Kurang layak & Revisi dengan pengubahan \\
\hline
\end{tabular}

\section{HASIL}

Hasil penelitian pengembangan strategi pembelajaran menulis puisi reflektif terdiri atas tiga paparan. Ketiga paparan tersebut, meliputi (1) deskripsi produk, (2) penyajian data hasil uji coba produk, dan (3) revisi produk. Berikut adalah uraian untuk ketiga paparan hasil tersebut.

\section{Deskripsi Produk}

Produk dari penelitian pengembangan ini adalah strategi pembelajaran menulis puisi reflektif yang diwujudkan dalam bentuk buku panduan penerapan strategi dan ditujukan untuk guru. Strategi pembelajaran menulis puisi reflektif terdiri atas empat tahap, yaitu (1) Refleksi Pengalaman, (2) Penulisan Puisi, (3) Perbaikan Unsur Puitika, serta (4) Penyuntingan dan Penyempurnaan. Keempat tahap di dalam strategi pembelajaran menulis puisi reflektif tersebut merupakan hasil pemaduan dua teori, yaitu proses berpikir reflektif dan proses menulis kreatif puisi.

Strategi pembelajaran menulis puisi reflektif adalah strategi pembelajaran yang dikembangkan dan dirancang untuk kompetensi dasar menulis puisi dengan memerhatikan bait, larik, rima, irama, imaji, dan isi. Kompetensi tersebut berada pada jenjang kelas X SMA Peminatan Bahasa Indonesia. Strategi pembelajaran menulis puisi reflektif berfokus pada puisi reflektif sebagai hasil belajar dan berorientasi pada tujuan moral serta penguatan karakter positif siswa. Oleh karena itu, sumber ide penulisan puisi reflektif dalam strategi pembelajaran tersebut berasal dari pengalaman berkesan yang membawa perubahan bagi kehidupan siswa sebagai perbaikan sikap moral maupun sosial.

Buku panduan penerapan strategi pembelajaran menulis puisi reflektif ini terdiri atas dua bab. Bab pertama membahas tentang konsep dasar strategi pembelajaran menulis puisi reflektif yang meliputi tujuh hal. Ketujuh hal tersebut adalah (1) hakikat puisi reflektif, (2) kedudukan puisi reflektif di dalam pembelajaran, (3) pengertian strategi pembelajaran menulis puisi reflektif, (4) karakteristik strategi pembelajaran menulis puisi reflektif, (5) tahapan strategi pembelajaran puisi reflektif, (6) isi pembelajaran dan faktor pendukung strategi pembelajaran menulis puisi reflektif, serta (7) keunggulan dan kelemahan strategi pembelajaran menulis puisi reflektif. Bab kedua membahas tentang penerapan strategi pembelajaran menulis puisi reflektif. Pada bab tersebut, penerapan strategi pembelajaran menulis puisi reflektif diuraikan secara sistematis, terinci, dan operasional dalam setiap tahapannya yang meliputi tahap (1) Refleksi Pengalaman, (2) Penulisan Puisi, (3) Perbaikan Unsur Puitika, dan (4) Penyuntingan dan Penyempurnaan. Selain itu, penerapan strategi pembelajaran menulis puisi yang diuraikan pada bab kedua juga disertai dengan contoh intruksi dan contoh hasil aktivitas belajar.

\section{Penyajian Data Hasil Uji Coba Produk}

Penelitian pengembangan ini menghasilkan produk strategi pembelajaran yang dikemas dalam bentuk buku panduan penerapan strategi pembelajaran menulis puisi reflektif. Buku panduan tersebut melewati dua tahap uji, yaitu (1) uji kelayakan oleh ahli dan praktisi serta (2) uji coba lapangan terbatas. Penyajian data dari kedua tahap uji tersebut dibedakan menjadi empat jenis data yang meliputi (1) kelayakan konsep strategi pembelajaran menulis puisi reflektif, (2) kelayakan langkah-langkah strategi pembelajaran menulis puisi reflektif dalam pembelajaran menulis puisi, (3) kelayakan strategi pembelajaran menulis puisi reflektif terhadap tingkat pemahaman dan kebutuhan siswa, serta (4) deskripsi hasil implementasi strategi pembelajaran menulis puisi reflektif dalam pembelajaran menulis puisi.

\section{Kelayakan Konsep Strategi Pembelajaran Menulis Puisi Reflektif}

Aspek kelayakan pertama adalah konsep strategi pembelajaran menulis puisi reflektif. Pada aspek tersebut, terdapat tiga subaspek yang dinilai, yaitu (1) konsep dasar strategi pembelajaran menulis puisi reflektif, (2) relevansi strategi pembelajaran menulis puisi reflektif dengan kurikulum, dan (3) kesesuaian strategi pembelajaran menulis puisi reflektif dengan prinsip menulis puisi. Pertama, sub aspek konsep dasar strategi pembelajaran menulis puisi reflektif mendapat persentase kelayakan sebesar 90\% dengan status layak implementasi. Kedua, sub aspek relevansi strategi pembelajaran menulis puisi reflektif dengan kurikulum memperoleh persentase kelayakan sebesar $90 \%$ dengan status layak implementasi. Ketiga, sub aspek kesesuaian strategi pembelajaran menulis puisi reflektif dengan prinsip menulis puisi mendapatkan persentase kelayakan sebesar 86,7\% dengan status layak implementasi. Dengan demikian, rata-rata persentase kelayakan konsep strategi pembelajaran menulis puisi reflektif adalah $88,9 \%$ dan tergolong layak implementasi. 


\section{Kelayakan Langkah-Langkah Strategi Pembelajaran Menulis Puisi Reflektif dalam Pembelajaran Menulis Puisi}

Aspek kelayakan kedua adalah langkah-langkah strategi pembelajaran menulis puisi reflektif dalam pembelajaran menulis puisi. Pada aspek tersebut, terdapat empat sub aspek yang dinilai, yaitu (1) relevansi strategi dengan pelaksanaan pembelajaran menulis puisi, (2) kedayagunaan strategi pembelajaran menulis puisi reflektif, (3) penyajian langkah-langkah kegiatan di dalam strategi pembelajaran menulis puisi reflektif, serta (4) relevansi strategi pembelajaran menulis puisi reflektif dengan proses reflektif menulis puisi. Pertama, sub aspek relevansi strategi dengan pelaksanaan pembelajaran menulis puisi mendapatkan persentase sebesar $86 \%$ dan tergolong layak implementasi. Kedua, sub aspek kedayagunaan strategi pembelajaran menulis puisi reflektif mendapatkan persentase sebesar 92\% sehingga layak implementasi. Ketiga, penyajian langkah-langkah kegiatan di dalam strategi pembelajaran menulis puisi reflektif memperoleh persentase sebesar $100 \%$ sehingga layak diimplementasikan. Keempat, relevansi strategi pembelajaran menulis puisi reflektif dengan proses reflektif menulispuisi memperoleh persentase sebesar 73,3\% sehingga berstatus revisi sesuai dengan catatan ahli dan praktisi. Dengan demikian, ratarata persentase kelayakan langkah-langkah strategi pembelajaran menulis puisi reflektif dalam pembelajaran menulis puisi adalah $87,8 \%$ dan tergolong layak implementasi.

\section{Kelayakan Strategi Pembelajaran Menulis Puisi Reflektif terhadap Tingkat Pemahaman dan Kebutuhan Siswa}

Aspek kelayakan ketiga adalah strategi pembelajaran menulis puisi reflektif terhadap tingkat pemahaman dan kebutuhan siswa. Pada aspek tersebut terdapat dua subaspek yang dinilai, yaitu (1) kesesuaian strategi menulis puisi reflektif dengan tingkat pemahaman dan kebutuhan siswa memperoleh persentase sebesar $84 \%$ sehingga berstatus dapat diimplementasikan dengan sedikit revisi, serta (2) akurasi strategi pembelajaran menulis puisi reflektif di dalam pembelajaran menulis puisi yang berstatus layak implementasi karena memperoleh persentase sebesar $90 \%$. Dengan demikian, rata-rata persentase kelayakan strategi pembelajaran menulis puisi reflektif terhadap tingkat pemahaman dan kebutuhan siswa adalah $87 \%$ dan tergolong layak implementasi.

\section{Hasil Implementasi Strategi Pembelajaran Menulis Puisi Reflektif dalam Pembelajaran Menulis Puisi}

Implementasi strategi pembelajaran menulis puisi reflektif dideskripsikan dari hasil uji coba lapangan terbatas yang menghasilkan dua macam data, yaitu data yang dihimpun dari angket siswa dan data berupa deskripsi hasil penerapan strategi pembelajaran menulis puisi reflektif dalam pembelajaran menulis puisi. Angket siswa terdiri atas 12 pernyataan yang berhubungan dengan tiga aspek, yaitu (1) kesan siswa terhadap pembelajaran menulis puisi reflektif, (2) keterpanduan siswa dalam melaksanakan aktivitas menulis puisi dengan strategi pembelajaran menulis puisi reflektif, serta (3) kepraktisan dan kemudahan siswa dalam menulis puisi dengan strategi pembelajaran menulis puisi reflektif. Berdasarkan ketiga aspek tersebut, siswa memberikan respon positif terhadap strategi pembelajaran menulis puisi reflektif. Hal tersebut dapat diketahui dari tingginya persentase setiap butir pernyataan yang berkisar pada angka 88,2\%-96,5\%. Hasil penghitungan keseluruhan menunjukkan bahwa strategi pembelajaran menulis puisi reflektif memperoleh persentase kelayakan sebesar 92,1\%. Dengan demikian, strategi pembelajaran menulis puisi reflektif layak diimplementasikan. Dari angket tersebut juga dihimpun komentarkomentar siswa yang menyatakan beberapa hal yang meliputi (1) setelah mengikuti pembelajaran menulis puisi reflektif, siswa menjadi lebih termotivasi dan ingin menulis puisi, (2) siswa menjadi lebih mudah dalam menulis puisi karena mengetahui cara mendapatkan ide dan menuangkan ide tersebut ke dalam paduan kata-kata yang puitik, serta (3) siswa menjadi lebih mudah dalam menulis puisi karena ada tahapan proses yang jelas, mudah dimengerti, dan mudah dipraktikkan.

Selain data yang dihimpun dari angket siswa, juga terdapat data berupa deskripsi hasil implementasi strategi pembelajaran menulis puisi reflektif yang meliputi empat tahap, yaitu tahap (1) Refleksi Pengalaman, (2) Penulisan Puisi, (3) Perbaikan Unsur Puitika, serta (4) Penyuntingan dan Penyempurnaan. Berikut adalah uraian tentang sajian data hasil implementasi strategi pembelajaran menulis puisi reflektif.

Pertama, Tahap Refleksi Pengalaman dilaksanakan pada pertemuan pertama, yaitu pada hari Rabu, 18 Oktober 2017. Pada tahap tersebut, siswa memperoleh hasil belajar berupa tulisan narasi singkat tentang pengalaman berkesan yang membawa perubahan dalam kehidupan mereka. Secara umum, terdapat tiga kelompok topik pengalaman yang dipilih dan dinarasikan oleh siswa, yaitu permasalahan dalam keluarga, romansa remaja, dan pilihan hidup.

Kedua, Tahap Penulisan Puisi dilaksanakan pada pertemuan kedua, yaitu pada hari Kamis, 19 Oktober 2017. Pada implementasi tahap kedua tersebut, siswa memperoleh hasil belajar berupa draft puisi reflektif seperti contoh berikut.

Sabarku sudah habis

Cobaan ini semakin berat

Aku rindu ...

Bangun dengan wajah ceria

Polos yang putih

Aku, kini menahan sakit

Kini berteman dengannya

Teman yang setia

Kesedihan 


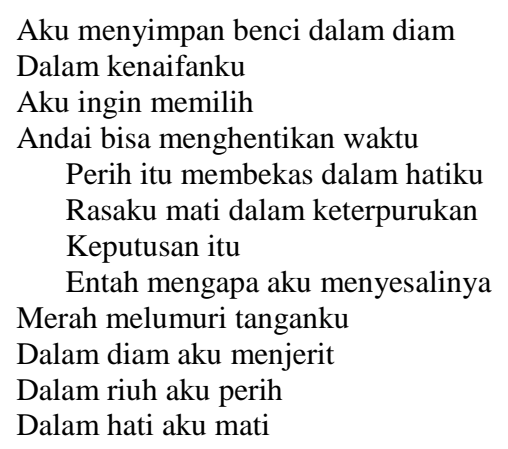

(PVD31)

Dari karya tersebut, tampak bahwa siswa sudah mampu menulis draft puisi reflektif. Pembangunan suasana muram, kesedihan, dan keputusasaan sudah terbangun dengan baik. Pada unsur pilihan kata atau diksi, tampak bahwa siswa cenderung menggunakan kata yang lugas dan sering digunakan sehari-hari, seperti sabar, cobaan, kesedihan, dan lain-lain. Selain itu, unsur citraan yang digunakan di dalam puisi tersebut belum kuat dalam menghadirkan imaji bagi pembaca. Penggunaan majas sebagai perbandingan juga belum bervariasi, terutama pada distribusinya. Dengan demikian, dari draft puisi karya siswa tersebut tampak bahwa unsur pilihan kata, kekayaan citraan atau imaji, dan penggunaan bahasa figuratif atau majas masih belum bervariasi.

Ketiga, Tahap Perbaikan Unsur Puitika dilaksanakan pada pertemuan ketiga, yaitu pada hari Rabu, 25 Oktober 2017. Pada implementasi tahap ketiga tersebut, siswa melakukan perbaikan dan pengayaan terhadap unsur-unsur puitika pada draft karya puisinya. Berikut adalah salah satu draft puisi karya siswa yang telah diperbaiki unsur puitikanya.

\section{Jeritan Hati}

Seribu tahun menjalani

Rintangan ini semakin berat

Aku rindu

Bangun dengan wajah ceria

Bagai polosnya kertas putih

Aku kini menahan sakit

Kini berteman dengannya

Teman yang setia

Awan kelabu

Kini menanti datangnya sinar

Yang menghangatkan hari-hariku

Yang menerangi kelamku

Yang menghapus kebencianku

Perih itu membekas dalam hatiku

Dalam kenaifanku, ingin ku memilih

Andaiku bisa menghentikan waktu

Keputusan itu

Entah aku menyesalinya

Merah melumuri tanganku

Dalam diam aku menjerit

Dalam riuh aku perih

Dalam hati aku mati (PVD31)

Pada puisi karya PVD31 tersebut, perbaikan yang dilakukan adalah pengubahan beberapa pilihan kata. Pada bait pertama, diksi sabar digantikan dengan seribu tahun untuk memperkuat kesan bahwa kesabaran yang dirasakan oleh aku liris sudah dirasakan dalam waktu yang sangat lama. Diksi cobaan digantikan dengan rintangan untuk memperjelas bahwa ujian kesabaran yang dihadapi oleh aku liris di dalam puisi bersifat lebih konkret. Artinya, ujian tersebut tidak hanya berupa ujian mental, tetapi juga hal-hal yang bersifat fisikal sehingga diperjelas menjadi rintangan. Pada bait kedua juga terdapat penggantian diksi, yaitu diksi kesedihan yang diubah menjadi awan kelabu. Pengubahan tersebut menunjukkan bagaimana PVD31 mencitrakan kesedihan yang dialaminya sebagai sebuah pertanda alam, yaitu awan mendung berwarna kelabu yang akan menciptakan hujan, yang ketika datang akan langsung melingkupi seluruh bagian langit dengan warna kelabu. Kesedihan itu langsung melingkupi seluruh perasaannya seperti awan mendung yang menutupi langit ketika akan hujan. Pengubahan diksi kesedihan menjadi awan kelabu sebenarnya mengandung makna yang unik karena tereferensi pada gejala alam yang bersifat temporer. Diksi tersebut merefleksikan harapan aku liris bahwa kesedihan yang dirasakannya bersifat temporer dan akan menghilang begitu keadaan menjadi lebih baik. Harapan tersebut berkorelasi kuat dengan bait ketiga puisi Jeritan Hati. 
Selain pengubahan diksi dan penambahan bait, perbaikan unsur puitika pada puisi tersebut juga terlihat pada penggunaan majas pada bait pertama larik kelima. Pada puisi yang belum direvisi, larik kelima pada bait pertama tersebut berbunyi /Polos yang putih/, sedangkan larik kelima pada bait pertama di puisi yang telah direvisi menjadi /Bagai polosnya kertas putih/. Dengan demikian, unsur majas yang ditambahkan adalah majas simile di mana sebuah objek dibandingkan dengan objek lain secara tidak langsung.

Citraan pada bait kelima pada puisi Jeritan Hati memunculkan pula sebuah refleksi dengan sangat kuat. Bait tersebut menggambarkan sebuah tindakan bunuh diri dengan memotong urat nadi pada pergelangan tangan hingga mengeluarkan darah yang cukup banyak dan dipertegas pula dengan penggambaran perasaan yang bersifat kontradiktif dengan lingkungan aku liris di dalam puisi, yaitu larik /Dalam diam aku menjerit/Dalam riuh aku perih. Citraan-citraan tersebut merefleksikan kesepian dan keputusasaan mendalam. Pada akhirnya, refleksi keputusasaan tersebut dinyatakan pada larik /Dalam hati aku mati/ yang menegaskan bahwa PVD31 sebagai aku liris tidak lagi bisa merasakan gairah hidup.

Keempat, Tahap Penyuntingan dan Penyempurnaan dilaksanakan pada pertemuan ketiga, yaitu pada hari Rabu, 25 Oktober 2017. Berikut adalah contoh puisi karya siswa pada tahap penyuntingan dan penyempurnaan.

\section{Jeritan Hati}

$\begin{array}{ll}\text { Seribu tahun menjalani } & (1) \\ \text { Rintangan ini semakin berat } & (2) \\ \text { Aku rindu } & (3) \\ \text { Bangun dengan wajah ceria } & (4) \\ \text { Bagai polosnya kertas putih } & (5) \\ \text { Aku kini menahan sakit } & (6) \\ \text { Kini berteman dengannya } & (7) \\ \text { Teman yang setia } & (8) \\ \text { Awan kelabu } & (9) \\ \text { Kini menanti datangnya sinar } & (10) \\ \text { Yang menghangatkan hari-hariku } & (11) \\ \text { Yang menerangi kelamku } & (12) \\ \text { Yang menghapus kebencianku } & (13) \\ \quad \text { Perih itu membekas dalam hatiku } & (14) \\ \quad \text { Dalam kenaifanku, ingin ku memilih } & (15) \\ \text { Andaiku bisa menghentikan waktu } & (16) \\ \text { Keputusan itu } & (17) \\ \text { Entah aku menyesalinya } & (18) \\ \text { Merah melumuri tanganku } & (19) \\ \text { Dalam diam aku menjerit } & (20) \\ \text { Dalam riuh aku perih } & (21) \\ \text { Dalam hati aku mati } & (22)\end{array}$

\section{(PVD31)}

Pada puisi tersebut, terdapat refleksi yang cukup beragam. Refleksi pertama berkaitan dengan penggambaran aku liris bahwa kehidupannya sangat menyedihkan, yaitu pada bait kedua larik ketujuh, kedelapan, dan kesembilan. Ketiga larik tersebut mengungkapkan bahwa kehidupan aku liris tidak pernah lepas dari kesedihan. Kesedihan tersebut direfleksikan melalui penggunaan diksi awan kelabu yang tereferensi pada gejala alam yang temporer. Hal itulah yang merefleksikan harapan $a k u$ liris bahwa kesedihan yang melingkupi hidupnya seperti awan kelabu yang menutupi langit ketika akan hujan akan menghilang setelah keadaan hidupnya menjadi lebih baik. Dengan demikian, refleksi pertama yang muncul pada puisi tersebut adalah pernyataan yang tertuang melalui diksi awan kelabu.

Refleksi kedua adalah pemilihan keputusan, tetapi tidak dibarengi dengan rencana tindakan. Pemilihan keputusan tersebut terwujud pada bait ketiga larik kesepuluh yang menyebutkan bahwa aku liris menantikan datangnya sinar yang dapat dipahami sebagai perubahan situasi di dalam hidupnya menuju ke arah yang lebih positif. Refleksi ketiga muncul pada bait keempat larik kedelapan belas. Pada keseluruhan bait ketiga, diungkapkan bahwa di masa lalunya sosok aku liris pernah melakukan suatu keputusan atau tindakan yang membawa dampak tidak baik. Oleh karena itu, muncul refleksi berupa rasa sesal yang disampaikan secara lugas pada bait keempat larik kedelapan belas yang berbunyi /Entah aku menyesalinya/.

Refleksi keempat berupa tindakan dan tertuang pada bait kelima larik kesembilan belas yang berbunyi /Merah melumuri tanganku/. Larik tersebut mengambarkan sebuah tangan yang terluka hingga mengeluarkan banyak darah. Jika dihubungkan dengan keputusan yang disesali pada bait keempat, dapat diindikasikan bahwa luka pada tangan tersebut memang sengaja dilakukan. Dengan kata lain, larik /Merah melumuri tanganku/ merupakan refleksi dari tindakan bunuh diri yang pernah dilakukan aku liris. Dengan demikian, refleksi yang teridentifikasi dari puisi Jeritan Hati karya PVD31 meliputi (1) refleksi pada tingkat pernyataan berupa diksi awan kelabu, (2) refleksi pada tingkat pemilihan keputusan berupa larik, yaitu bait ketiga larik kesepuluh, (3) refleksi pada tingkat pernyataan berupa larik, yaitu bait keempat larik kedelapan belas, dan (4) refleksi pada tigkat tindakan berupa larik, yaitu bait kelima larik kesembilan belas. Keempat refleksi tersebut memiliki hubungan yang sangat unik karena kesinambungannya tidak berurutan dengan pola a-d-c-b. Pola tersebut berarti poin a sebagai awal masalah yaitu 
kesedihan yang dalam membawa aku liris melakukan tindakan yang tidak baik untuk dirinya (poin b). Setelah melakukan tindakan tersebut, aku liris menyesali tindakan tersebut (poin c) dan memutuskan untuk bersabar dalam menanti keadaan yang lebih baik di dalam hidupnya (poin d).

\section{Revisi Produk}

Setelah uji validasi dan uji coba lapangan terbatas dilakukan, panduan penerapan strategi pembelajaran menulis puisi reflektif direvisi sesuai saran perbaikan yang diberikan oleh ahli puisi, ahli pembelajaran puisi, dan praktisi bahasa Indonesia. Revisi tersebut dilakukan pada aspek (1) kelayakan konsep strategi pembelajaran menulis puisi reflektif, (2) kelayakan langkahlangkah strategi pembelajaran menulis puisi reflektif dalam pembelajaran menulis puisi reflektif, (3) kelayakan strategi pembelajaran puisi reflektif terhadap tingkat pemahaman dan kebutuhan siswa, serta (4) revisi produk berdasarkan hasil uji lapangan terbatas.

\section{Revisi pada Konsep Strategi Pembelajaran Menulis Puisi Reflektif}

Pada aspek kelayakan konsep strategi pembelajaran menulis puisi reflektif, ahli puisi dan ahli pembelajaran puisi memberikan pendapat yang serupa terhadap teknis penyajian konsep dasar dan contoh penerapan langkah-langkah strategi pembelajaran menulis puisi reflektif di dalam panduan penerapan strategi. Kedua ahli menyebutkan bahwa sajian deskripsi konsep strategi berupa landasan pengembangan strategi, konsep dasar, langkah-langkah, contoh implementasi, hingga isi pembelajaran masih terlihat tumpang tindih dan belum sistematis sehingga membutuhkan pengorganisasian ulang. Berdasarkan pendapat tersebut, perbaikan yang dilakukan pada panduan penerapan strategi pembelajaran menulis puisi reflektif adalah menata ulang substansi dari komponen-komponen yang termaktub di dalam konsep strategi pembelajaran menulis puisi reflektif. Sajian yang bersifat teoretis dikelompokkan menjadi satu ke dalam bab pertama sehingga bab kedua hanya berisi contoh implementasi strategi yang disertai instruksi operasional serta contoh hasil aktivitas belajar.

\section{Revisi pada Langkah-Langkah Strategi Pembelajaran Menulis Puisi Reflektif dalam Pembelajaran Menulis Puisi}

Pada aspek kelayakan yang kedua, ahli puisi menyatakan bahwa deskripsi langkah-langkah di dalam strategi membutuhkan pengayaan pada penugasan bagi siswa karena belum bervariasi. Selain itu, aktivitas belajar di dalamnya juga masih terkesan melompat karena ada tahap yang terlewati. Terkait dengan kekurangan tersebut, perbaikan yang dilakukan adalah (1) menambah variasi bentuk penugasan dan (2) menambahkan tahap aktivitas belajar siswa untuk mengatasi kesenjangan tahap yang dimaksud.

Selain ahli puisi, ahli pembelajaran puisi juga berpendapat bahwa deskripsi langkah-langkah strategi pembelajaran menulis puisi reflektif masih memerlukan pembenahan. Tahap pengubahan hasil refleksi pengalaman menjadi larik-larik puisi terkesan masih abstrak dan belum operasional, sehingga belum layak untuk diimplementasikan kepada siswa. Dari pendapat tersebut, perbaikan yang dilakukan adalah mengoperasionalkan kembali tahap pengubahan refleksi pengalaman menjadi puisi dengan memperjelas aktivitas belajar yang lebih konkret bagi siswa. Pengoperasionalan tersebut dilakukan dengan cara menambah satu aktivitas belajar untuk siswa. Setelah selesai memilah deskripsi pengalaman berdasarkan alur peristiwa, siswa tidak langsung mengimajinasikan peristiwa tersebut, tetapi merefleksikan apa yang dapat ditangkap dari setiap bagian pengalaman tersebut. Hal-hal yang direfleksikan antara lain suasana yang hadir dalam setiap bagian plot tersebut, refleksi sikap maupun gambaran sosok yang terlibat di dalam peristiwa tersebut, dan/atau nilai kehidupan apa yang dapat ditangkap dari setiap bagian peristiwa.

\section{Revisi pada Strategi Pembelajaran Menulis Puisi Reflektif terhadap Tingkat Pemahaman dan Kebutuhan Siswa}

Pada aspek kelayakan strategi pembelajaran puisi reflektif terhadap tingkat pemahaman dan kebutuhan siswa, ahli puisi memberikan pendapat bahwa pemanfaatan media pembelajaran dalam penerapan strategi tersebut perlu diperbaiki. Hal tersebut disebabkan oleh media pembelajaran yang digunakan di dalam penerapan strategi pembelajaran menulis puisi reflektif belum variatif. Selain itu, pemanfaatan media pembelajaran tersebut juga belum menunjukkan gradasi aktivitas berpikir reflektif bagi siswa.

Dari pendapat ahli puisi tersebut, perbaikan yang dilakukan adalah (1) menambah variasi media pembelajaran yang digunakan, (2) menambah contoh puisi reflektif yang lebih mudah dipahami dan aplikatif untuk siswa serta terintegrasi di dalam lembar kerja siswa, dan (3) menyajikan contoh puisi reflektif karya penyair Indonesia tidak hanya sebagai contoh yang dipaparkan begitu saja tetapi diintegrasikan ke dalam materi pengenalan puisi reflektif serta unsur-unsur puitikanya.

\section{Revisi berdasarkan Hasil Implementasi Strategi Pembelajaran Menulis Puisi Reflektif dalam Pembelajaran Menulis Puisi}

Strategi pembelajaran menulis puisi reflektif telah memenuhi kriteria kelayakan karena penghitungan keseluruhan jawaban siswa dari angket memperoleh persentase sebesar 92,1\% sehingga layak diimplementasikan. Tingkat kelayakan strategi pembelajaran menulis puisi reflektif juga memperoleh respon positif yang disampaikan melalui komentar siswa yang meliputi (1) setelah mengikuti pembelajaran menulis puisi reflektif, siswa menjadi lebih termotivasi dan ingin menulis puisi, (2) siswa menjadi lebih mudah dalam menulis puisi karena mengetahui cara mendapatkan ide dan menuangkan ide tersebut ke dalam 
paduan kata-kata yang puitik, serta (3) siswa menjadi lebih mudah dalam menulis puisi karena ada tahapan proses yang jelas, mudah dimengerti, dan mudah dipraktikkan.

Berdasarkan fakta penerapan strategi pembelajaran menulis puisi reflektif di lapangan, hal yang perlu diperhitungkan adalah waktu pelaksanaan pembelajaran. Pembelajaran menulis puisi dengan menerapkan strategi pembelajaran menulis puisi reflektif memakan waktu paling sedikit empat kali pertemuan. Oleh karena itu, efisiensi penyajian langkah-langkah belajar dari strategi pembelajaran menulis puisi reflektif serta kecepatan belajar siswa menjadi hal utama yang dipertimbangkan dalam menerapkan strategi tersebut. Selain itu, aspek pendukung pembelajaran yang lain juga turut menjadi perhatian. Pertama, suasana pembelajaran yang dibangun sebaiknya memperhatikan kenyamanan siswa, baik kenyamanan dalam belajar maupun kenyamanan personal. Hal tersebut disebabkan siswa akan melakukan proses refleksi terhadap pengalamannya yang bersifat sangat pribadi. Kedua, ketersediaan sarana pembelajaran yang mendukung penerapan strategi pembelajaran menulis puisi reflektif. Dalam pelaksanaan pembelajaran menulis puisi dengan strategi menulis puisi reflektif, terdapat penggunaan media pembelajaran yang bersifat audio visual. Akan tetapi, sifat penggunaannya dapat disesuaikan dan diimprovisasikan oleh guru karena bergantung pada sarana belajar yang tersedia di sekolah. Oleh karena itu, faktor pendukung berupa pembangunan suasana belajar dan ketersediaan sarana pembelajaran ditambahkan ke dalam muatan produk panduan penerapan strategi pembelajaran menulis puisi reflektif.

\section{PEMBAHASAN}

Pada pengembangan strategi pembelajaran menulis puisi reflektif, pembahasan data yang dilakukan meliputi empat aspek. Keempat aspek tersebut adalah (1) konsep strategi pembelajaran menulis puisi reflektif, (2) langkah-langkah strategi pembelajaran menulis puisi reflektif dalam pembelajaran menulis puisi, (3) strategi pembelajaran menulis puisi reflektif terhadap tingkat pemahaman dan kebutuhan siswa, serta (4) bentuk implementasi strategi pembelajaran menulis puisi reflektif dalam pembelajaran menulis puisi pada uji coba lapangan terbatas.

\section{Konsep Strategi Pembelajaran Menulis Puisi Reflektif}

Strategi pembelajaran menulis puisi reflektif adalah strategi pembelajaran yang dikembangkan untuk kompetensi menulis puisi pada jenjang kelas X SMA. Strategi tersebut dikembangkan dengan memadukan dua proses berpikir, yaitu proses berpikir reflektif dan proses kreatif menulis puisi. Dengan memadukan kedua proses tersebut, siswa diharapkan mampu memproduksi karya puisi berupa puisi reflektif yang merefleksikan pemikiran dan sudut pandang mereka terhadap suatu masalah atau peristiwa yang diwujudkan secara unik, estetik, dan orisinal melalui eksplorasi keterampilan berbahasa berupa puisi. Hal tersebut sesuai dengan hakikat puisi, yaitu karya yang tidak hanya menyampaikan isi pikiran, perasaan, maupun luapan emosi penulisnya, tetapi juga menunjukkan cara berpikir dan pandangan pribadi masing-masing penyair terhadap suatu hal (Bolton, 2014; DiYanni, 2001).

Dalam pengembangan strategi pembelajaran yang dikemas ke dalam bentuk buku panduan, pengorganisasian konsep strategi, tahapan strategi, penyajian langkah-langkah belajar di dalam strategi, hingga contoh implementasi strategi dan latihan untuk siswa harus diorganisasikan dengan baik, sistematis, dan teratur (Wena, 2010). Hal tersebut dilakukan agar sasaran utama pengguna buku panduan — dalam konteks ini adalah guru — dapat memahami esensi isi strategi, penyajian langkah dan aktivitas belajar, serta pemanfaatan materi dan media yang tertuang di dalam strategi secara tepat sehingga penerapan strategi dalam pembelajaran dapat terlaksana dengan baik.

Berdasarkan saran dari ahli puisi dan ahli pembelajaran puisi, pengorganisasian sajian isi buku Panduan Penerapan Strategi Pembelajaran sebaiknya ditata ulang agar batasan antarsajian menjadi lebih jelas dan sistematis. Oleh karena itu, sajian deskripsi konsep strategi berupa landasan pengembangan strategi, konsep dasar, langkah-langkah, contoh implementasi, hingga isi pembelajaran pada produk Panduan Penerapan Strategi Pembelajaran Menulis Puisi Reflektif diorganisasikan ulang. Hasil pengorganisasian ulang tersebut menghasilkan sajian isi panduan yang terdiri atas dua bab. Bab pertama membahas tentang Konsep Dasar Strategi Pembelajaran Menulis Puisi Reflektif yang meliputi tujuh hal. Ketujuh hal tersebut adalah (1) Hakikat Puisi Reflektif, (2) Kedudukan Puisi Reflektif di dalam Pembelajaran, (3) Pengertian Strategi Pembelajaran Menulis Puisi Reflektif, (4) Karakteristik Strategi Pembelajaran Menulis Puisi Reflektif, (5) Tahapan Strategi Pembelajaran Puisi Reflektif, (6) Isi Pembelajaran dan Faktor Pendukung Strategi Pembelajaran Menulis Puisi Reflektif, serta (7) Keunggulan dan Kelemahan Strategi Pembelajaran Menulis Puisi Reflektif. Bab kedua membahas tentang Penerapan Strategi Pembelajaran Menulis Puisi Reflektif. Pada bab tersebut, penerapan strategi pembelajaran menulis puisi reflektif diuraikan secara sistematis, terinci, dan operasional dalam setiap tahapannya yang meliputi (1) Tahap Refleksi Pengalaman, (2) Tahap Penulisan Puisi, (3) Tahap Perbaikan Unsur Puitika, serta (4) Tahap Penyuntingan dan Penyempurnaan. 


\section{Langkah-Langkah Strategi Pembelajaran Menulis Puisi Reflektif dalam Pembelajaran Menulis Puisi}

Persentase kelayakan langkah-langkah pembelajaran menulis puisi reflektif mencapai angka 87,8\% sehingga berstatus layak implementasi. Esensi dari strategi pembelajaran menulis puisi reflektif adalah muatan berupa tahapan aktivitas yang di dalamnya berisi langkah-langkah belajar dengan tujuan untuk membimbing siswa dalam berproses kreatif menulis puisi. Oleh karena itu, sistematika urutan dan tingkat keoperasionalan langkah-langkah belajar di dalamnya menjadi dua hal yang harus diperhatikan.

Berdasarkan kedua hal tersebut, ahli puisi dan ahli pembelajaran puisi memberikan komentar bahwa terdapat kesenjangan di dalam langkah-langkah strategi, yaitu pada langkah pengubahan hasil refleksi pengalaman menjadi larik-larik puisi. Langkah tersebut masih terkesan abstrak dan belum operasional. Dengan demikian, perbaikan yang dilakukan adalah menambahkan langkah belajar dan mengubah redaksional kalimat instruksi menjadi lebih operasional dengan penyertaan contoh hasil aktivitas. Penambahan langkah belajar tersebut memang menambah beban belajar siswa, tetapi memberikan arahan yang lebih jelas dan konkret untuk berproses kreatif menulis puisi. Jika kesenjangan tersebut tidak diatasi dengan menambahkan aktivitas belajar dan menyertakan contoh yang lebih konkret, siswa justru tidak mampu berproses kreatif sesuai dengan apa yang diharapkan guru dan tujuan pembelajaran. Hal tersebut sesuai dengan pernyataan Wommelsduff (2005) bahwa proses kreatif dalam diri siswa tidak akan berjalan dengan optimal jika guru memberikan kebebasan tak terbatas dalam proses menulis puisi.

Ahli puisi juga memberikan saran untuk memvariasikan bentuk-bentuk dan kompleksitas penugasan yang diberikan kepada siswa. Penambahan variasi dan kompleksitas penugasan dilakukan dengan memampatkan beberapa langkah reflektif dengan memvariasikan bentuk penugasan siswa yang terkait dengan proses berpikir reflektif. Bentuk penugasan awal yang tadinya hanya menjawab pertanyaan, diperluas menjadi pengisian urutan kronologi pengalaman, penarasian pengalaman berkesan yang membawa perubahan dalam kehidupan siswa, dan secara bertahap menuju penugasan penulisan puisi yang lebih kompleks. Pemvariasian bentuk latihan untuk siswa tidak hanya menunjukkan perbedaan bentuk latihan, tetapi menunjukkan pula gradasi kesulitan latihan yang dapat meningkatkan dan/atau memperkuat pemahaman atau keterampilan siswa (Olinghouse, 2008). Hal tersebut senada dengan pendapat Wena (2010) yang menyatakan bahwa latihan yang diberikan selanjutnya lebih kompleks daripada latihan yang telah dikerjakan.

\section{Strategi Pembelajaran Menulis Puisi Reflektif Terhadap Tingkat Pemahaman dan Kebutuhan Siswa}

Aspek strategi pembelajaran menulis puisi reflektif terhadap tingkat pemahaman dan kebutuhan siswa mendapatkan persentase kelayakan sebesar $87 \%$ sehingga berstatus layak implementasi. Meskipun demikian, ahli puisi menyarankan adanya perbaikan pada pemanfaatan media pembelajaran yang belum variatif dan belum menunjukkan gradasi aktivitas berpikir reflektif bagi siswa. Berdasarkan saran tersebut, perbaikan yang dilakukan meliputi tiga hal. Pertama, menambah variasi media pembelajaran yang digunakan yang pemanfaatannya ditata sedemikian rupa sehingga membentuk gradasi aktivitas berpikir reflektif. Oleh karena itu, media audio visual yang digunakan pertama kali adalah iklan inspiratif yang refleksinya terlihat dengan jelas dalam durasi singkat dan ditunjukkan oleh pelaku peran yang jumlahnya sedikit, kemudian disusul dengan video atau film pendek inspiratif yang proses refleksinya disampaikan secara implisit melalui alur dan jumlah pelaku peran yang lebih banyak. Pemanfaatan media pembelajaran tersebut pada akhirnya akan membentuk penciptaan kondisi belajar-yaitu proses berpikir reflektif - untuk mencapai kompetensi dasar yang dituju, yaitu menulis kreatif puisi yang berpusat pada siswa dan dengan memanfaatkan media pembelajaran (Sukirno, 2009).

Kedua, menambah contoh puisi reflektif yang lebih mudah dipahami dan aplikatif untuk siswa serta terintegrasi di dalam lembar kerja siswa. Contoh puisi reflektif yang digunakan sebagai contoh pada Panduan Penerapan Strategi Pembelajaran Menulis Puisi Reflektif dan lembar kerja siswa adalah buatan peneliti dan bersumber dari pengalaman hidup peneliti sendiri. Hal tersebut dimaksudkan agar siswa ikut memperoleh dan merasakan pengalaman yang mengesankan serta membawa perubahan yang dialami oleh peneliti dan terwujud ke dalam bentuk puisi. Dalam penerapan strategi pembelajaran menulis puisi reflektif yang konkret dan ideal, guru dapat memodifikasi contoh puisi reflektif dengan puisi tulisan sendiri agar guru dapat membimbing subjek didik secara langsung dalam memberikan pengalaman yang mengesankan, menyentuh, dan menggelitik (Endraswara, 2005). Ketiga, menyajikan contoh puisi reflektif karya penyair Indonesia tidak hanya sebagai contoh tetapi diintegrasikan ke dalam materi pengenalan puisi reflektif serta unsur-unsur puitikanya. Hal tersebut dimaksudkan agar siswa dapat memahami seperti ciri-ciri puisi reflektif dan bentuk-bentuk pengungkapan refleksi di dalam puisi. Selain itu, penyajian contoh puisi reflektif karya penyair Indonesia yang terintegrasi di dalam materi juga membantu siswa untuk mengalami gradasi proses berpikir reflektif yang diawali dari refleksi nilai pada media audio visual berupa iklan dan video/film pendek inspiratif menuju refleksi nilai pada media yang lebih implisit, yaitu puisi tertulis.

\section{Implementasi Strategi Pembelajaran Menulis Puisi Reflektif dalam Pembelajaran Menulis Puisi}

Pada implementasi strategi pembelajaran menulis puisi reflektif di lapangan, respon yang ditunjukkan siswa bersifat positif. Hal tersebut didukung dengan komentar siswa yang dihimpun dari angket siswa yang meliputi (1) peningkatan keinginan dan motivasi siswa dalam menulis puisi menulis puisi, (2) kemudahan yang dirasakan siswa dalam menulis puisi karena mengetahui cara mendapatkan ide dan menuangkan ide tersebut ke dalam paduan kata-kata yang puitik, serta (3) 
kemudahan siswa dalam menulis puisi karena ada tahapan proses yang jelas, mudah dimengerti, dan mudah dipraktikkan. Selain itu, persentase rata-rata kelayakan strategi pembelajaran menulis puisi reflektif yang dihimpun dari angket uji lapangan terbatas yang diisi siswa mencapai angka 92,1\% sehingga berstatus layak diimplementasikan.

Selain pembahasan terhadap data angket siswa, pembahasan juga diarahkan pada hasil implementasi strategi pembelajaran menulis puisi reflektif yang meliputi empat tahap, yaitu tahap (1) Refleksi Pengalaman, (2) Penulisan Puisi, (3) Perbaikan Unsur Puitika, dan (4) Penyuntingan dan Penyempurnaan. Berikut adalah uraian tentang pembahasan hasil implementasi strategi pembelajaran menulis puisi reflektif.

Pertama, tahap pertama yang diimplementasikan dari strategi pembelajaran menulis puisi reflektif adalah Refleksi Pengalaman. Tahap tersebut difungsikan sebagai tahap penggalian ide, di mana siswa harus peka dalam mengumpulkan, memilah, dan memilih pengalaman berkesan yang membawa perubahan untuk menjadi ide puisinya. Selain peka dalam menentukan pengalaman sebagai ide puisi, siswa juga diharapkan menjadi peka terhadap segala unsur di dalam pengalaman tersebut untuk merefleksikan nilai-nilai yang ada didalamnya. Dengan kata lain, untuk dapat memilih pengalaman yang membawa perubahan di dalam hidup dan merefleksikan nilai-nilai didalamnya, siswa harus peka dalam menangkap fenomena kehidupan (Endraswara, 2003).

Hasil belajar siswa yang didapat dari implementasi Tahap Refleksi Pengalaman adalah narasi dan refleksi siswa terhadap pengalaman berkesan yang dipilih. Berdasarkan temuan lapangan, terdapat tiga kelompok topik besar dari pengalaman berkesan dan di dalamnya terdapat subtopik yang lebih kecil. Berikut adalah rincian kelompok topik dan subtopik pengalaman berkesan yang dipilih siswa (Tabel 2).

Tabel 2. Topik dan Subtopik Pengalaman Berkesan Siswa pada Tahap Refleksi Pengalaman

\begin{tabular}{cll}
\hline No. & Topik Pengalaman yang Dipilih & \multicolumn{1}{c}{ Subtopik dari Pengalaman yang Dipilih } \\
\hline 1. & Permasalahan dalam Keluarga & Menghadapi Perceraian Orangtua \\
2. & Romansa Remaja & Kehilangan Anggota Keluarga \\
3. & Pilihan Hidup & Perasaan Terabaikan dalam Keluarga \\
& & Kekaguman terhadap Lawan Jenis yang Berakhir Tragis \\
& & Patah Hati \\
& & Kekecewaan karena Merasa Berada di Tempat yang Salah \\
& & Penerimaan dan upaya bangkit dari kegagalan \\
& & Eksistensi diri \\
\hline
\end{tabular}

Ketiga topik dan variasi subtopik dari masing-masing pengalaman yang dipilih dan dinarasikan oleh siswa menunjukkan adanya titik krisis. Dengan kata lain, siswa mengalami keadaan yang tidak menyenangkan, tidak nyaman, dan menekan aspek psikis pada pengalaman-pengalaman tersebut. Situasi yang menimbulkan tekanan pada mental dapat mendorong munculnya motivasi dalam diri siswa untuk mengungkapkan perasaan dan pemikiran terhadap ketidaknyamanan tersebut. Bentuk pengungkapan tersebut tidak hanya melalui penuturan langsung, tetapi juga dapat melalui bentuk eksplorasi bahasa yang lebih halus, seperti menulis puisi. Hal tersebut sejalan dengan pendapat Maulana (2015) dan Dini (1983) yang menyatakan bahwa luapan-luapan perasaan terkuat baru bisa dituliskan jika ada sebuah pengalaman yang mengguncang hati atau menimbulkan keharuan.

Kedua, tahap kedua yang diimplementasikan adalah Tahap Penulisan Puisi. Pada tahap tersebut, hasil belajar siswa adalah (1) siswa mampu memilah narasi yang telah ditulis sebelumnya ke dalam bagian-bagian alur, (2) siswa mampu merefleksikan unsur-unsur yang ada di dalam setiap bagian alur peristiwa yang berupa gambaran sosok tokoh yang terlibat, kesan dan suasana yang ada di dalam peristiwa tersebut, dan nilai atau pelajaran hidup yang dapat dirumuskan dari peristiwa tersebut, (3) siswa mampu mengimajinasikan bagian-bagian alur peristiwa sebagai peristiwa simbolis, baik secara keseluruhan maupun sebagian, (4) siswa mampu mengumpulkan diksi puitis berdasarkan hasil pengimajinasian, (5) siswa mampu merangkai larik-larik puisi dengan menggunakan diksi yang telah dikumpulkan, dan (6) siswa mampu menulis larik-larik yang telah dibuatnya ke dalam susunan bait menjadi draft puisi yang utuh. Dari kualitas draft puisi yang dihasilkan siswa pada implementasi Tahap Penulisan Puisi, tampak bahwa terdapat beberapa unsur puitika yang belum tergarap dengan baik. Unsurunsur puitika yang dimaksud adalah (1) penggunaan pilihan kata yang terkesan umum dan belum puitis, (2) penggunaan majas sebagai perbandingan masih belum mencukupi untuk menimbulkan kesan makna yang lebih dalam, dan (3) harmonisasi bunyi atau rima pada sebagian besar draft puisi belum tergarap dengan baik.

Ketiga, tahap ketiga dalam strategi pembelajaran menulis puisi reflektif adalah Tahap Perbaikan Unsur Puitika. Hasil belajar siswa dari implementasi strategi tahap ketiga tersebut adalah (1) siswa mampu memperbaiki dan memperkaya penggunaan unsur puitika di dalam puisinya, (2) siswa mampu memperbaiki kesatuan ide dan pembangunan suasana di dalam puisinya, dan (3) siswa mampu memberikan judul yang sesuai dengan puisi yang ditulis. Dari kualitas draft puisi yang dihasilkan siswa pada implementasi Tahap Perbaikan Unsur Puitika, tampak kemajuan pada perbaikan yang dilakukan siswa. Kemajuan tersebut mencakup hal-hal berikut, (1) penggunaan diksi yang lebih puitis dan figuratif dalam mengungkapkan suatu pemaknaan di dalam puisi, (2) citraan yang muncul lebih kaya dan mendukung pembangunan suasana puisi, (3) harmonisasi bunyi lebih tertata, baik dalam satuan larik maupun bait, dan (4) penggunaan majas sudah bervariasi. Selain itu, pada tahap 
ketiga tersebut, pemikiran dan sudut pandang siswa sudah terefleksikan pada penggunaan diksi khusus yang figuratif sehingga memiliki fungsi sebagai citraan dan majas. Temuan tersebut sejalan dengan pendapat Kennedy dan Guioa (1994:95—96) yang menyatakan bahwa refleksi terwujud sebagai metafora dan bahasa figuratif yang mengandung makna prismatis di dalam puisi.

Keempat, tahap keempat yang diimplementasikan adalah Tahap Penyuntingan dan Penyempurnaan. Hasil belajar yang dicapai siswa pada implementasi tahap tersebut adalah (1) siswa mampu memberikan kritik, saran, dan/atau komentar terhadap karya puisi milik temannya dan (2) siswa mampu memperbaiki karya puisinya berdasarkan kritik, saran, dan/atau komentar teman pasangan kerja. Temuan lain dari implementasi Tahap Penyuntingan dan Penyempurnaan adalah munculnya tingkatan refleksi di dalam puisi karya siswa yang meliputi keempat tingkatan refleksi, yaitu (1) pertanyaan, (2) pernyataan, (3) pemilihan keputusan yang diikuti dengan rancangan tindakan, serta (4) tindakan. Bentuk pengungkapan refleksi berdasarkan struktur puisi yang muncul pada puisi karya siswa meliputi pengungkapan dalam tingkat diksi, larik, dan bait.

\section{SIMPULAN}

Produk yang dihasilkan pada penelitian pengembangan ini adalah buku Panduan Penerapan Strategi Pembelejaran Menulis Puisi Reflektif yang penggunaannya ditujukan untuk guru. Panduan Penerapan Strategi Pembelajaran Menulis Puisi Reflektif tersebut terdiri atas dua bab. Bab pertama membahas tentang konsep dasar strategi pembelajaran menulis puisi reflektif yang meliputi tujuh hal. Ketujuh hal tersebut adalah (1) hakikat puisi reflektif, (2) kedudukan puisi reflektif di dalam pembelajaran, (3) pengertian strategi pembelajaran menulis puisi reflektif, (4) karakteristik strategi pembelajaran menulis puisi reflektif, (5) tahapan strategi pembelajaran puisi reflektif, (6) isi pembelajaran dan faktor pendukung strategi pembelajaran menulis puisi reflektif, serta (7) keunggulan dan kelemahan strategi pembelajaran menulis puisi reflektif. Bab kedua membahas tentang penerapan strategi pembelajaran menulis puisi reflektif. Pada bab tersebut, penerapan strategi pembelajaran menulis puisi reflektif diuraikan secara sistematis, terinci, dan operasional dalam setiap tahapannya yang meliputi tahap (1) Refleksi Pengalaman, (2) Penulisan Puisi, (3) Perbaikan Unsur Puitika, dan (4) Penyuntingan dan Penyempurnaan. Selain itu, penerapan strategi pembelajaran menulis puisi yang diuraikan pada bab kedua juga disertai dengan contoh intruksi dan contoh hasil aktivitas belajar.

Hasil penelitian yang diperoleh mencakup empat aspek yang meliputi (1) kelayakan konsep strategi pembelajaran menulis puisi reflektif, (2) kelayakan langkah-langkah strategi pembelajaran menulis puisi reflektif dalam pembelajaran menulis puisi, (3) kelayakan strategi pembelajaran menulis puisi reflektif dengan tingkat pemahaman dan kebutuhan siswa, serta (4) hasil implementasi strategi pembelajaran menulis puisi reflektif. Pertama, aspek kelayakan strategi pembelajaran menulis reflektif layak diimplementasikan karena mendapatkan persentase sebesar 88,9\% dengan melakukan perbaikan pada pengorganisasian substansi isi strategi. Kedua, aspek kelayakan langkah-langkah strategi pembelajaran menulis puisi reflektif dalam pembelajaran menulis puisi layak diimplementasikan karena mendapatkan persentase sebesar 87,8\% dengan melakukan perbaikan yang meliputi (1) penambahan langkah belajar dan pengubahan redaksional kalimat instruksi menjadi lebih operasional dengan penyertaan contoh hasil aktivitas, serta (2) penambahan variasi dan kompleksitas penugasan siswa yang terkait dengan proses berpikir reflektif. Ketiga, aspek kelayakan strategi pembelajaran menulis puisi reflektif dengan tingkat pemahaman dan kebutuhan siswa layak diimplementasikan karena memperoleh persentase sebesar 87\% dengan melakukan perbaikan yang meliputi (1) penambahan variasi media pembelajaran untuk membentuk gradasi aktivitas berpikir reflektif, (2) penambahan contoh puisi reflektif yang lebih mudah dipahami, aplikatif, dan terintegrasi di dalam LKS, serta (3) pengintegrasian contoh puisi reflektif karya penyair Indonesia ke dalam materi pengenalan puisi reflektif serta unsur-unsur puitikanya. Keempat, hasil implementasi strategi pembelajaran menulis puisi reflektif menunjukkan bahwa strategi tersebut layak diimpmelentasikan karena mendapatkan persentase sebesar 92,1\% dengan mempertimbangkan (1) penghitungan alokasi waktu pelaksanaan pembelajaran dan kecepatan belajar siswa, (2) pembangunan suasana belajar, dan (3) ketersediaan sarana pembelajaran. Berdasarkan paparan tersebut, strategi pembelajaran menulis puisi reflektif layak diimplementasikan dalam pembelajaran menulis puisi pada jenjang kelas X SMA.

Berdasarkan hasil implementasi strategi pembelajaran menulis puisi reflektif pada uji coba lapangan terbatas, ditemukan bahwa puisi karya siswa memiliki tingkat refleksi yang beragam yaitu meliputi tingkat (1) pertanyaan, (2) pernyataan, (3) pemilihan keputusan, baik yang diikuti dengan rancangan tindakan maupun tidak, serta (4) tindakan. Pengungkapan refleksi berdasarkan unsur puitika tertuang pada diksi, citraan, dan majas dalam puisi karya siswa. Selanjutnya, bentuk pengungkapan refleksi berdasarkan struktur puisi yang muncul pada puisi karya siswa meliputi pengungkapan dalam tingkat diksi, larik, dan bait.

Saran diberikan berdasarkan aspek pemanfaatan produk, diseminasi, dan pengembangan lebih lanjut. Pertama, saran pemanfaatan ditujukan kepada Guru Bahasa Indonesia, khususnya pada jenjang Sekolah Menengah Atas, bahwa pemilihan dan pemanfaatan media pembelajaran untuk strategi pembelajaran menulis puisi reflektif akan lebih baik jika dilakukan langsung oleh guru agar sesuai deng kebutuhan siswa serta ketersediaan sarana dan sumber belajar yang ada. Selain itu, dalam melaksanakan pembelajaran menulis puisi reflektif, guru dapat berimprovisasi dalam membangun suasana belajar yang nyaman bagi siswa misalnya dengan mengadakan pembelajaran di luar kelas agar siswa menjadi lebih bebas dalam menentukan ruangnya sendiri. 
Kedua, saran diseminasi ditujukan kepada semua pihak agar produk dapat disebarluaskan melalui (1) kegiatan-kegiatan seminar akademik yang membahas tentang pembelajaran Bahasa Indonesia di sekolah, (2) penulisan artikel dalam jurnal pendidikan yang berbasis cetak maupun daring, (3) kegiatan-kegiatan pelatihan untuk guru Bahasa Indonesia, terutama pelatihan tentang pembelajaran kompetensi menulis kreatif, dan (4) dikirimkan kepada pihak penerbitan buku untuk dicetak dan disebarluaskan dalam skala yang lebih besar.

Ketiga, peneliti lebih lanjut disarankan agar mengkaji kembali produk strategi pembelajaran menulis puisi reflektif untuk menemukan titik kelemahan, sehingga dapat diperbaiki dan dioptimalkan sebagai pijakan dalam mengembangkan strategi pembelajaran menulis puisi yang lebih inovatif, kreatif, dan secara aktual menjawab kebutuhan pembelajaran di lapangan.

\section{DAFTAR RUJUKAN}

Arikunto, S. (2009). Dasar-Dasar Evaluasi Pendidikan. Jakarta: Bumi Aksara.

Atmowiloto, A. (1983). Pengalaman Menulis dan Proses Kreatif. Dalam Pamusuk Eneste (Ed.), Proses Kreatif: Mengapa dan Bagaimana Saya Mengarang. Jakarta: Gramedia.

Bolton, G. (2014). Reflective Practice: Writing and Professional Development. London: SAGE Publications.

Borg, W. R., Gall, M.D., \& Gall, J. P. (2003). Educational Research: An Introduction (Seventh Edition). New York: Pearson Education.

Dini, N. H. (1983). Naluri yang Mendasari Penciptaan. Dalam Pamusuk Eneste (Ed.), Proses Kreatif: Mengapa dan Bagaimana Saya Mengarang (hlm.110-124). Jakarta: Gramedia.

DiYanni, R. (2001). Literature: Reading Fiction, Poetry, and Drama. Singapore: McGraw-Hill Books.

Endraswara, S. (2003). Membaca, Menulis, Mengajarkan Sastra. Yogyakarta: Penerbit Kota Kembang.

Endraswara, S. (2005). Metode dan Teori Pengajaran Sastra: Berwawasan Kurikulum Berbasis Kompetensi. Yogyakarta: Buana Pustaka.

Hullfish, G., \& Smith, P.G. (1964). Reflective Thinking: The Method of Education. New York: Feffer and Simons, Inc.

Kennedy, X.J., \& Guioa, D. (1994). An Introduction to Poetry. New York: Harper Collins College Publisher.

Lickona, T. (1992). Educating for Character: How Our School Can Teach Respect and Responsibilty. New York: Bantam

Books.

Maulana, S.F. (2015). Apresiasi dan Proses Kreatif Menulis Puisi. Bandung: Nuansa Cendekia.

Morley, D. (2007). The Cambridge Introduction to Creative Writing. Cambridge: Cambridge University Press.

Naylor, A., \& Wood, A.B. (2012). Teaching Poetry: Reading and Responding to Poetry in Secondary Classroom. New York: Routledge.

Olinghouse, N. (2008). Designing Lessons for Diverse Learner. Accomodating and Modifying for Divers Learner, 94(7):1-8. Retrieved from http://education.msu.edu/te/elementary/pdf/designing-lessons-for-diverse-learners.pdf.

Rahmanto, B. (2000). Metode Pengajaran Sastra. Yogyakarta: Kanisius.

Rodgers, C. (2002). Defining Reflection: Another Look at John Dewey and Reflective Thinking. Teachers College Record, 104(4), 842 - 866. Retrieved from http://www.bsp.msu.edu/uploads/files/Reading_Resources/Defining_Reflection.pdf.

Roseboro, A. J. (2010). Teaching Middle School Language Arts: Incorporating Twenty-First Century Literacies. Lanham: Rowman and Littlefield Publisher.

Situmorang, S. (1984). Usaha Rekonstruksi yang Dirundung Ragu. Dalam Pamusuk Eneste (Ed.), Proses Kreatif II: Mengapa dan Bagaimana Saya Mengarang (hlm.1-20). Jakarta: Gramedia.

Sukirno. (2009). Pembelajaran Menulis Kreatif dengan Strategi Belajar Akselerasi. Purworejo: UM Purworejo Press.

Waluyo, H. J. (1987). Teori dan Apresiasi Puisi. Jakarta: Erlangga.

Wena, M. (2010). Strategi Pembelajaran Inovatif Kontemporer: Suatu Tinjauan Konseptual Operasional. Jakarta: Bumi Aksara. Widijanto, T. (2014). Menulis Sastra, Siapa Takut? Yogyakarta: Pustaka Puitika.

Wommelsduff, D. (2005). The Paradox of Structure and Freedom: An Experiment in Writing Poetry. English Journal, 94(4), 23-39. http://search.proquest.com/docview/237302460/fulltextPDF/5065BA27618A4A76PQ/1?accountid=38628 